\title{
Coping under pressure: Strategies for maintaining confidence amongst South African soccer coaches
}

\author{
Authors: \\ Jhalukpreya Surujlal ${ }^{1}$ \\ Sheila Nguyen ${ }^{2}$ \\ Affiliations: \\ ${ }^{1}$ Faculty of Management \\ Sciences, Vaal University of \\ Technology, South Africa \\ ${ }^{2}$ Faculty of Business \\ and Law, School of \\ Management and \\ Marketing, Deakin \\ University, Australia \\ Correspondence to: \\ Jhalukpreya Surujlal \\ Email: \\ babs@vut.ac.za \\ Postal address: \\ Private Bag X021, \\ Vanderbijlpark 1900, South \\ Africa \\ Dates: \\ Received: 16 Jan. 2010 \\ Accepted: 11 Aug. 2010 \\ Published: 23 Feb. 2011 \\ How to cite this article: \\ Surujlal, J. \& Nguyen, \\ S., 2011, 'Coping under \\ pressure: Strategies for \\ maintaining confidence \\ amongst South African \\ soccer coaches', Health \\ SA Gesondheid 16(1), Art. \\ \#537, 7 pages. doi:10.4102/ \\ hsag.v16i1.537
}

(C) 2011. The Authors. Licensee: OpenJournals Publishing. This work is licensed under the Creative Commons Attribution License.
Sport coaching can be a fulfilling and rewarding occupation, but can also be stressful because of the demands and expectations of various external factors. The complex and extraordinary demands placed on coaches, force them to perform multiple roles (e.g. educator, motivator, counsellor, adviser, trainer, manager and administrator). Soccer coaches face a number of challenges, frustrations, conflicts and tensions, the enormity of which is often underestimated. This notion is supported by the description of coaching as a perilous occupation in which coaches experience pressures like stress, conflict and tension, media pressure and intrusions into family life. This study explored the perceptions of South African soccer coaches in terms of the mechanisms they use to cope with potential stressors experienced in their jobs and employed a non-experimental design, using a quantitative approach, to assess stress and coping strategies of South African coaches. One hundred and twelve soccer coaches, coaching at the provincial level and higher, completed a questionnaire on stress and stress coping mechanisms used in their coaching jobs. Descriptive data analysis was completed using the Statistical Package for Social Sciences (SPSS - version 16). The sources of stress experienced and coping methods used by the coaches were evaluated. Results revealed that the top three sources of stress were a lack of resources, fixture backlog and games where the outcome is critical, whilst the lowest three sources of stress were political interference, physical assaults from players and substituting a player. Moreover, various coping strategies used by the coaches showed that an average of $5.68 \%, 5.14 \%$ and $89.78 \%$ of the sample used maladaptive coping, emotion management coping and problem management coping strategies respectively. Academic and practical implications of the study results are discussed.

Sport afrigting kan 'n baie vervullende en bevredigende beroepskeuse wees, maar as gevolg van die eise en verwagtinge van verskeie omgewings faktore, kan dit ook as 'n spanningsvolle beroep ervaar word. Afrigters moet verskeie rolle vertolk (o.a. opvoeder, motiveerder, sielkundige, adviseerder, afrigter, bestuurder en administrateur) wat deel uitmaak van die komplekse en buitengewone eise wat op hulle geplaas word. Sokker afrigters beleef ' $n$ aantal uitdagings, konflik situasies, frustrasies en spanning waarvan die impak of waarde daarvan selde gemeet kan word. Afrigting as 'n konsep word beskryf of gedefinieer as 'n potensieel onveilige en/of wisselvallige beroep waar die meerderheid afrigters spanning ervaar, konflik beleef, media druk moet verwerk en 'n geweldige inbreuk op hul persoonlike en familielewe ervaar. Hierdie studie ondersoek Suid-Afrikaanse sokker afrigters se persepsies aangaande die meganismes wat hulle gebruik om die potensiële spanning van hul beroep te bestuur. Die studie is gebaseer op ' $n$ nie-eksperimentele ontwerp met ' $n$ kwantitatiewe benadering van Suid-Afrikaanse sokker afrigters om spanning te evalueer en te bestuur. Een honderd en twaalf sokker afrigters wat op provinsiale vlak of hoër afgerig het, het vraelyste ingevul aangaande spanning en spanning hanteringstegnieke wat in hul afrigtingsberoepe gebruik is. Beskrywende data analise is met behulp van 'n statistiese pakket in Sosiale Wetenskap (SPSS-weergawe 16) gedoen. Die oorsake van spanning asook die hanteringstegnieke wat deur die afrigters gebruik is, is geevalueer. Die resultate het bevind dat daar drie duidelike oorsake van spanning was, naamlik 'n tekort aan hulpbronne, die akkumulasie van geskeduleerde wedstryde asook wedstryde waarvan die uitslag krities is. Die drie laagste oorsake van spanning was onder andere politieke inmenging, fisiese aanranding deur spelers en die vervanging van spelers. Die afrigters het ' $n$ verskeidenheid van spannings hanteringstegnieke gebruik, maar die resultate toon dat $5.68 \%, 5.14 \%$ en $89.78 \%$ van die eksperimentele groep oneffektiewe spannings-, emosionele- en probleem bestuurstegnieke geïmplementeer het. Akademiese en praktiese implikasies van die navorsingsresultate word bespreek.

\section{Introduction}

Sport coaching can be a fulfilling and rewarding occupation, but it can also be stressful (Malone \& Rotella 1991:22; Kelley \& Gill 1993:96; Kroll \& Gendersheim 1982:47; Steelman 1995:14) because of the demands and expectations of various external factors (e.g. increased job demands, excessive 
workloads, conflicting roles and the pressure to win all competitions as well as handle defeat), especially for those whose careers and livelihoods are dependent on it. This 'chaotic lifestyle' includes travel, being away from family and friends, long and undefined hours and limited time for oneself; these considerations inevitably contribute to increased levels of stress amongst sport coaches (McNamara 2007:1). The complexity and extraordinary demands placed on coaches include performing a myriad of duties, such as assuming the role of educator, motivator, counsellor, adviser, trainer, manager and administrator (Surujlal 2004:111). Coaches are also consistently put to the test, as they are responsible for athletes and their performance (Wynd 2007:2).

Apart from the external factors contributing to stressful working environments, soccer coaches face further challenges, frustrations, conflicts and tensions. These often result from volatile interactions with players, facilitating athletes' performances, mediating relationships between athletes and enduring scrutiny from athletes, fans and media (Taylor 1992:27); the enormity of which is often underestimated. Singh (2001:72) alludes to this notion by describing coaching as a perilous occupation in which coaches experience pressures like stress, conflict and tensions, media pressures and intrusions into family life. Experiences such as these can contribute significantly to the levels of pressure experienced by coaches whose behaviour is mostly characterised by an excessively competitive drive and a chronic sense of urgency in terms of time. Zylanski and Jenkins (cited in Sadri \& Marcoulides 1997:33) found that this type of behaviour has a clear link with stress-related outcomes, as individuals often underestimate the time and effort required to accomplish tasks and therefore experience abnormal levels of stress (rated by the National Institute of Occupational Safety and Health in the United States of America [Minter 1991:40] as one of the most dangerous or crippling work-related illnesses) which occur when job demands exceed an individual's adaptive resources (Lazarus \& Folkman 1984:19; Smith 1986:41). Carson and Kuipers (1998:161) proposed three levels in the stress process. Firstly, stressors come from external sources specifically related to the occupation (e.g. high job demands, lack of resources and lack of support from management). Secondly, it could include variables that act as moderators which, in turn, act as buffers against the negative effects of stress on individuals. Thirdly, the stress process consists of stress outcomes, which may be positive (e.g. mental and physical well-being) or negative (e.g. burnout and ill health). The proposed stress models have illustrated stress as a by-product of the ratio of demands on resources in order to cope with demands (Smith 1986:41). Bhagat et al. (2001:302) posit that stress experienced by individuals in their organisational context and the extent to which adverse effects occur is dependent on how the stressor is perceived (e.g. locus of control) and the effectiveness of the coping strategy adopted by individuals. Pearlin and Schooler (1978:2) describe coping as behaviour that mediates the impact that societies have on their members by protecting them from psychological harm caused by problematic social experiences. It is not unidimensional and functions at a number of levels and is attained by a 'plethora of behaviours, cognitions and perceptions' (Pearlin \& Schooler 1978:8). It represents the efforts, both behavioural and cognitive, that people invest in dealing with stressful encounters (Pienaar \& Rothmann 2003:81). It can also be associated with concepts such as mastery, defence and adaptation. For the purpose of this study, coping is referred to as any strategy or response to stress that assists in preventing, avoiding or reducing stress.

Coping strategies have been described as problem-focused coping, emotion-focused coping and avoidance-focused or maladaptive coping (Burton \& Raedeke 2008; Parker \& Endler 1992:339). Problem-focused coping strategies seek to deal actively with the problem, whilst emotion-focused strategies focus on dealing with the emotional distress caused by the problem. Avoidance or a maladaptive approach involves the individuals removing themselves from the problem situation.

Research (Burton \& Raedeke 2008; Smith 1986:47; Wolfson \& Neave 2007:242) has identified different strategies that help individuals explain and deal with negative experiences. In various studies, several significant patterns of coping have emerged. Burke (1993:173) found that maladaptive behaviours such as excessivealcohol intake, drug use, smoking and overeating are prevalent in the police force, whilst Van der Bijl and Oosthuizen (2007:48) found that teachers resorted to smoking and drinking and doctors prescribe medication for themselves. In their study on soccer referees, Wolfson and Neave (2007:233) have identified the blaming others for failure whilst taking credit for success, distorting or ignoring unpleasant information and interpreting one's motives as principled and righteous as methods of maintaining confidence in difficult circumstances. Taylor and Brown (1994:22) further suggest that misrepresenting reality with positive illusions could be healthy and adaptive for coaches. They go on to specify that it assists in removing perceptions of self-blame, which enables coaches to protect themselves from external censure, reduces depression and offers plausible explanations for disturbing events. McAuley and Duncan (1989:189) found that athletes and coaches often dealt with unpleasant experiences and disappointing results by blaming external factors such as bad luck or other people's incompetence. It has been acknowledged that there are potential limitations with these studies on attribution responses. Other potentially useful mechanisms identified include self-aggrandisement where individuals believe that they have more positive qualities than others (Alicke 1985:1622). This increases their belief in themselves and makes them more confident.

\section{Problem statement}

South Africa's re-entry into the international sporting arena in 1991 has resulted in heightened competition, both nationally and internationally (Surujlal \& Singh 2007:84), compelling sport organisations to raise the bar in terms of their expectations of coaches. In the past, when professional soccer was still in its infancy, the primary task of coaches was 
to urge players onto a training ground on a freezing night and to impart some knowledge before players fled back to the warmth of their homes. Today coaches are required to do much more. Coaches are now called upon to perform an array of functions and face a multitude of conflict situations, many of which could contribute to increased pressure. Due to the fluctuating job market, it is difficult to leave coaching and start a new career (Malone \& Rotella 1981:22). It is therefore important for them to cope with the unavoidable stress associated with this profession.

South African soccer has experienced a high turnover of coaches in the past, with an increasing number of coaches being dismissed by clubs who are impatient for success. During the 2003 soccer season, seven coaching changes took place in the South African Premier Soccer League with the season barely two months old. Four coaches in this 16-team league vacated their seats in one day, suggesting that something was amiss. According to Mark (2002:17), the career of the soccer coach is increasingly short-lived because the pressure upon them is high. Success in soccer coaching is dependent on several variables which include resources (facilities and players), support from management, fixture schedule (home and away), strength of the opposition and the competence of the coach. A lack of any of these variables could contribute to the lack of success, which ultimately will result in stress experienced by the coach.

In the past few decades, the issue of occupational stress has been receiving increased research attention. It has been identified as a significant area of study in view of the amount of time people spend on work-related activities (Mostert \& Joubert 2005:40). Despite the problem surrounding growing levels of stress and its negative consequences, soccer coaches continue to go unrecognised not only by coaches themselves but also by sport organisations. Owing to the dearth of studies, particularly in the South African context, strategies employed by soccer coaches in order to cope with coachingrelated stressors are explored in this study.

\section{Purpose of the study}

This study was designed for South African soccer coaches to convey their perceptions in terms of the mechanisms used to cope with potential stressors, which are seen as problematic in their job. The purpose is to descriptively explore the sources of stress and coping methods used by soccer coaches in South Africa.

\section{Research method and design Sample}

The study adopted a purposive sampling technique. Purposive samples are information-rich cases that can be studied in depth (Patton 1990). It is a non-representative subset of a larger population (in this instance, soccer coaches) and is constructed to serve a very specific need or purpose. We approached 112 soccer coaches, whose main source of income was from coaching and who coached at provincial level and higher, to complete a questionnaire on stress related to their job. These coaches were selected because they are more visible to the general public in comparison to lower-level coaches (Hjalm et al. 2007:415). Of the coaches that were approached $(N=112), 88(N=88,79 \%)$ completed the questionnaire. The sample comprised $86 \%$ male coaches $(n=76)$ with the remaining $14 \%$ represented by female coaches $(n=12)$. Furthermore, $81.3 \%$ of the coaches were involved with male soccer players, $14.8 \%$ coached female soccer players and $3.4 \%$ coached both male and female soccer players. The respondents' ages ranged from 20 years to $56+$ years, with the highest represented group (mode) being within the $36-40$ years age bracket $(34.1 \%, n=30)$. Most coaches $(77.3 \%, n=78)$ had between 6 and 15 years' coaching experience and were employed through a coaching contract $(94.3 \%, n=83)$. With regard to coaching qualifications, most coaches $(81.8 \%, n=72)$ had either a level 1 or level 2 qualification.

\section{Instrument}

A questionnaire, which was adapted from a study conducted by Wolfson and Neave (2007:235), was designed for the soccer coaches in order to collect demographic data and perceptions relating to stress. Wolfson and Neave's (2007) study researched coping strategies adopted by soccer referees. The decision to adapt the questionnaire was based on the relevancy of the questions to South African soccer coaches. More specifically, the items had content validity as these items were validated in their use with a similar sample. The instrument was therefore both relevant and appropriate for the needs of this study. Information regarding gender, age, years of experience as a coach, type of employment, academic qualifications, coaching qualifications, income level, percentage of time spent coaching, the gender of team members being coached and sources of stress were obtained. In addition, coaches were requested to indicate their responses to various methods used to cope with stress. Specifically, the coping strategy items represented:

1. problem management (5 items)

2. emotion management (7 items)

3. maladaptive (4 items) coping method approaches to stress.

\section{Procedure}

The study employed a non-experimental design using a quantitative approach to assess stress and coping strategies of South African coaches. A trained fieldworker was employed to administer the questionnaire to the participants. Participants were identified at different stadia where they coached, at stadia where soccer matches took place, as well as at clubhouses of different teams. In most instances, the questionnaires were completed in the presence of the fieldworker after matches and training sessions. In other instances, they were completed by the coaches at their convenience and later collected by the fieldworker. Data from the usable responses $(N=88)$ were descriptively analysed to 
provide an overview of sources of stress and coping methods employed. Data analyses were conducted using the Statistical Package for Social Sciences (SPSS - version 16).

\section{Results}

From the descriptive analysis, sources of stress experienced (Table 1) and coping methods used (Table 2) by the coaches were evaluated. The results (Table 1) revealed that the top five sources of stress were:

- $\quad$ lack of resources $(M=3.80 ;$ s.d. $=0.51)$

- fixture backlog $(M=3.74 ;$ s.d. $=0.56)$

- games where the outcome is critical $(M=3.62 ;$ s.d. $=0.72)$

- $\quad$ contract violations $(M=3.57$; s.d. $=0.91)$

- poor refereeing decisions $(M=3.57$; s.d. $=0.87)$.

The lowest five sources of stress were ascribed to:

- political interference $(M=1.88$; s.d. $=0.99)$

- $\quad$ physical assaults from players $(M=1.97$; s.d. $=0.81)$

- substituting a player $(M=2.10 ;$ s.d. $=0.79)$

- cultural barriers $(M=2.11 ;$ s.d. $=0.95)$

- $\quad$ verbal abuse from players $(M=2.17$; s.d. $=0.97)$.

The means of stressors indicated that the stressors, at the very least, were mildly stressful with the most stressful being reported as having a strong contribution to stress. Furthermore, the standard deviations did not show much variation in the responses, indicating homogeneity across responses. A lack of resources was reported as the highest contributor to stress $(M=3.80$; s.d. $=0.51)$ and political interference was listed as the lowest source of stress. $(M=1.88 ;$ s.d. $=0.99)$.

Moreover, the study indicated that, in terms of various coping strategies employed by coaches, an average of $5.68 \%$ of the sample used maladaptive coping, an average of $51.47 \%$ of coaches used emotion management and an average of $89.78 \%$ of the sample relied on problem management (Table 2). This indicates that most of the coaches are using appropriate coping actions (i.e. problem management coping strategies) to deal with coaching-related stressors. Specifically, most of the coaches $(89 \%)$ noted that they 'tried to learn something from' the stressor and analysed what happened to better understand the stressful situation.

\section{Ethical considerations}

Participants were informed through means of a covering letter that their participation was voluntary, their responses

TABLE 1: Frequencies, Percentages, Means and Standard Deviations of Sources of Stress.

\begin{tabular}{|c|c|c|c|c|c|c|c|c|c|c|}
\hline \multirow[t]{2}{*}{ Sources of Stress } & \multirow[t]{2}{*}{$M$} & \multirow[t]{2}{*}{ s.d. } & \multicolumn{2}{|c|}{ Not at all } & \multicolumn{2}{|c|}{ Mildly } & \multicolumn{2}{|c|}{ Somewhat } & \multicolumn{2}{|c|}{ Strongly } \\
\hline & & & $f$ & $\%$ & $f$ & $\%$ & $f$ & $\%$ & $f$ & $\%$ \\
\hline \multicolumn{11}{|l|}{ Top 5} \\
\hline Poor refereeing decisions & 3.57 & 0.87 & 6 & 6.8 & 4 & 4.5 & 12 & 13.6 & 66 & 75.0 \\
\hline Contract violations & 3.57 & 0.91 & 7 & 8.0 & 4 & 4.5 & 9 & 10.2 & 68 & 77.3 \\
\hline Games where the outcome is critical (e.g. a local derby or relegation match) & 3.62 & 0.72 & 1 & 1.1 & 9 & 10.2 & 12 & 13.6 & 66 & 75.0 \\
\hline Fixture backlog & 3.74 & 0.56 & 0 & 0.0 & 5 & 5.7 & 13 & 14.8 & 70 & 79.0 \\
\hline \multicolumn{11}{|l|}{ Bottom 5} \\
\hline Political interference & 1.88 & 0.99 & 38 & 43.2 & 34 & 38.6 & 5 & 5.7 & 11 & 12.5 \\
\hline Physical assaults from players & 1.97 & 0.81 & 25 & 28.4 & 46 & 52.3 & 12 & 13.6 & 5 & 5.7 \\
\hline Substituting a player & 2.10 & 0.79 & 20 & 22.7 & 42 & 47.7 & 23 & 26.1 & 3 & 3.4 \\
\hline Cultural barriers & 2.11 & 0.95 & 25 & 28.4 & 38 & 43.2 & 15 & 17.0 & 10 & 11.4 \\
\hline Verbal abuse from players & 2.17 & 0.97 & 22 & 25.0 & 42 & 47.7 & 11 & 12.5 & 13 & 14.8 \\
\hline
\end{tabular}

s.d., Standard Deviation.

$f$, frequencies.

TABLE 2: Frequencies and Percentages of Coaches' Use of Coping Strategies.

\begin{tabular}{|c|c|c|c|}
\hline Type of Coping & Specific Coping Mechanism & $f$ & $\%$ \\
\hline \multirow[t]{4}{*}{ Maladaptive } & Nothing- just ignore it & 2 & 2.3 \\
\hline & Vent your frustrations on something or someone & 3 & 3.4 \\
\hline & Consume Alcohol & 4 & 4.5 \\
\hline & Smoke & 11 & 12.5 \\
\hline \multirow[t]{7}{*}{ Emotion Management } & Eat & 29 & 33.0 \\
\hline & Go out with your friends & 30 & 34.1 \\
\hline & Sleep or take a nap & 32 & 36.4 \\
\hline & Try to think of other things rather than dwell on it & 36 & 40.9 \\
\hline & Watch television & 51 & 58.0 \\
\hline & Exercise or do a workout & 61 & 69.3 \\
\hline & Remind yourself that you tried your best & 78 & 88.6 \\
\hline \multirow[t]{4}{*}{ Problem Management } & Talk to fellow colleagues about what has happened & 69 & 78.4 \\
\hline & Replay the situation in your mind and imaging what you should do & 71 & 80.7 \\
\hline & Seek help or advice & 81 & 920.0 \\
\hline & Analyse what is happening so you may understand it better & 87 & 98.9 \\
\hline
\end{tabular}

$f$, frequencies. 
would be confidential and that their participation would remain anonymous. Furthermore, the results would be presented in aggregate.

\section{Discussion}

South Africa's re-entry into the international sporting arena was fairly recent (in 1991) and has changed the dynamic of sport and sport coaching in South Africa (Surujlal \& Singh 2007:84). As a result, there is very little known about South African coaches and how this change has influenced South African sport and sport coaching. In light of this, this study explored the demographic profile of South African soccer coaches and, specifically, assessed sources of stress and coping methods as a means to better understand how the important variables of Smith's (1986:39-41) cognitiveaffective model on burnout is perceived by South African coaches.

It was found that South African soccer coaches are relatively young (between 36 and 40 years of age; 34.1\%; $n=30$ ) and most are equipped with between 6 and 10 years of coaching experience $(4.5 \% ; n=4)$. Whilst a majority of the teams are coached at the premier division $(n=29 ; 33 \%)$ and division $1(n=31 ; 35 \%)$, it is interesting to note that $94.3 \%(n=83)$ of the coaches were employed on a contract basis (versus permanent employment, $4.5 \% ; n=4)$. This is further exacerbated by the fact that most have only level $1(30.7 \% ; n=$ $27)$ or level $2(51.1 \% ; n=45)$ coaching qualifications. Similarly, Surujlal (2004:166) found that 9 out of 16 coaches in the South African Premier Soccer League (PSL) did not have any formal qualification in soccer coaching, but were nonetheless allowed to coach in the PSL. These incongruencies have been noted by many researchers (e.g. Anshel 2001:224; Burton \& Raedeke 2008; Hjalm et al. 2007:415; Smith 1986:42) who have alluded to the fact that stress developed in some cases such as when a mismatch existed between the perceived demands of the situation and coaches' capabilities and resources for meeting those demands. A consequence of this is that individuals may develop a negative attitude towards their job with co-workers further deteriorating the situation and ultimately leading to negative results such as burnout (e.g. Smith 1986:42; Vealey et al. 1992:40). This is further confirmed in our study's findings, which showed 'lack of resources' $(M=3.80 ;$ s.d. $=0.506)$ as the highest rated source of stress.

Moreover, the results of this study reflect the notion that the strongest stressors are often external and are mostly out of the control of the individual (Carson \& Kuipers 1998; Malone \& Rotella 1981). Specifically, when comparing the top five stressors and the lowest five sources of stress, it is notable that the stressors rated highest (e.g. lack of resources, fixture backlog, games where the outcome is critical, contract violations, poor refereeing decisions) are those that would most likely occur and have the most impact on coaching outcomes. In contrast, the lowest five sources of stress (e.g. political interference, physical assaults from players, substituting a player, cultural barriers and verbal abuse from players) were least likely to occur or were controlled by the respondents. The rated sources of stress illustrated the typical locus of control response where internal and external controls have differentiating impact on how a stressor is perceived (Rotter 1966). Specifically, those stressors deemed internal are more likely to cause less negative impact than those categorised as external, because levels of control decrease when stressors are considered outside the control of the individual. The impact of the types of stress and the level of support have been discussed in past research and models of stress (Burton \& Raedeke 2008; Hjalm et al. 2007:415; Smith 1986:42). Therefore, it is suggested that stress management and ensuing considerations of resources should match the level of responsibilities and should be evaluated and levelled by coaching development managers in terms of their strategies to nurture and maintain a healthy workforce.

Whilst these changes could provide positive effects for the South African coaching community, there are planning implications. For example, matching responsibility with support and/or resources will require an audit and discussion on what constitutes equity. Thus, issues of equity across the structure and resources of South African coaching will need to be broached and it will necessitate a clearer understanding of the nature of their various resources (e.g. human, financial and so on) (Misener \& Doherty 2009:478).

\section{Limitations and implications of the study}

Whilst this discussion focuses on the inequities of demands and resources, by providing a descriptive view of the sources of stress experienced and coping strategies employed by South African soccer coaches, not all angles relating to stress were explored. There are other areas of research that may provide more insight on stress management of South African soccer coaches. Firstly, an exploration of which specific dispositional and cognitive factors (e.g. gender, age, years of experience, perception of support and so on) affect type of coping and management of stress should be conducted as a confirmation of the cognitive-affective model of burnout (Kaissidis-Rodafinos, Anshel \& Porter 1997:427; Vealey et al. 1992:56; Smith 1986:39-41). The dispositional and cognitive factors could be complemented by an exploration of the impact of attitudes toward stress and other like psychographic variables. Furthermore, using multivariate statistical analyses to evaluate the levels of impact various factors (e.g. gender and education) have on coping styles and management should be considered (Kassisidis-Rodafinos et al. 1997:431; Kelley 1994:99). Predictive relationships and causal models with mediating and moderating influences should be considered in future research. Simply replicating the present study may reconfirm the findings. The insight from these efforts would provide the knowledge to address stress and stress management in coaching more effectively.

\section{Conclusion}

Coaches could play a vital role in managing their own stress. Instead of focusing totally on their profession, they should 
satisfy their personal needs (e.g. professional development, social life and family commitments). They should maintain an accurate perspective and, instead of focusing on the negative, react proactively towards anxiety, worry, problems and complaints (Malone \& Rotella 1981:22; Yong \& Yue 2007:78). Coaches should be flexible and learn from mistakes and failures by recognising them, admitting that a mistake has been made and correcting those mistakes (Malone \& Rotella 1981:22). The findings of this study can assist managers and coaches in targeting the major sources of stress and in focusing on the appropriate methods for coping most effectively (i.e. problem management coping).

A positive finding of the study revealed that the majority of the coaches employed problem management coping strategies (89.78\% average use) with fewer using emotion management $(51.47 \%$ average use) and maladaptive approaches (5.68\% average use). Whilst this is a positive result, soccer management in South Africa must formalise and implement programmes (e.g. coaching certificate and coach education) that will demonstrate healthy ways of managing stress encountered in the workplace. In particular, coaches should be advised on which methods are best to adopt in coping with stress, that is, problem-solving coping strategies (Burton \& Raedeke 2008; Parker \& Endler 1992:339). Integrating problem-solving coping strategies as part of their formal education will provide the necessary tools to diminish the occurrence of burnout and turnover in the relatively young South African professional soccer industry. As with the matching process, these changes have financial implications and will necessitate the examination of a workforce strategy to meet these challenges. Hiring new managers or training current managers to communicate the knowledge necessary to implement appropriate coping strategies must be considered. This study shows that challenges in terms of 'financial planning and management may become more critical and require more attention as the club grows and more people become involved' (Misener \& Doherty 2009:478).

From a management perspective, it is recommended that coaching in South African follow international trends which specify that when a coach enters into a contract with a club at provincial level or higher, the mother body should also be in possession of the contract. This would protect both parties from any deviation in terms of the contract which may negatively impact coaches' experience of their work environment (e.g. increasing stressful situations). Specifically, there should be a code of conduct, which both clubs and coaches should uphold, to negotiate the balance between demands and resources effectively. One such recommendation would be to implement professional development systems to enable coaches to be developed to the highest levels of coaching, especially because most coaches notably lacked the appropriate qualifications required for the position. This will provide a more balanced situation in terms of demands and/or resources to boost their confidence, make them more objective in their decision-making and reduce the number of mistakes they make, thereby reducing the pressure that they experience. The inequities seen in the profile of South African soccer coaches should also be addressed. This would be the first step towards providing a better coaching experience. Fortunately, South African soccer coaches are on a positive track in employing problem-solving coping strategies to deal with the growing pains of a developing coaching system.

\section{References}

Alicke, M.D., 1985, 'Global self-evaluation as determined by the desirability and controllability of trait adjectives', Journal of Personality and Social Psychology 49, 1621-1630.

Anshel, M.H., 2001, 'Qualitative validation of a model for coping with acute stress in sport', Journal of Sport Behavior 24, 223-246.

Bhagat, R.S., Ford, D.L., O'Driscoll, M.P., Frey, L., Babakus, E. \& Mahanyele, M., 2001 'Do South African managers cope differently from American managers? A crosscultural investigation', International Journal of Intercultural Relations 25, 301-313.

Burke, R.J., 1993, 'Work-family stress, conflict, coping and burnout in police officers', Stress Medicine 9, 171-180.

Burton, D. \& Raedeke, T.D., 2008, Sport psychology for coaches. Human Kinetics Campaign, Illinois.

Carson, J. \& Kuipers, E., 1998, 'Stress management interventions', in Hardy, S., Carson, J. \& Thomas, B. (eds.), Occupational stress: personal and professional approaches. Stanley Thornes, Cheltenham.

Frey, M., 2007, 'College coaches' experiences with stress-“problem solvers" have problems, too', The Sport Psychologist 21, 38-57.

Hjalm, S., Kentta, G., Hassmenan, P. \& Gustafsson, H., 2007, 'Burnout among elite soccer coaches', Journal of Sport Behaviour 30(4), 415-428.

Kaissidis-Rodafinos, A., Anshel, M.H. \& Porter, A., 1997, 'Personal and situational factors that predict coping strategies for acute stress among basketball referees', Journal of Sports Sciences 15, 427-436.

Kelley, B.C., 1994, 'A model of stress and burnout in collegiate coaches: effects of gender and time of season', Research Quarterly for Exercise and Sport 65(1), 48-59. PMid:8184211

Kelley, B.C. \& Gill, D.L., 1993, 'An examination of personal/situational variable, stress appraisal, and burnout in collegiate teacher-coaches', Research Quarterly for Exercise and Sport 64(1), 94-102.

Kroll, W. \& Gendersheim, J., 1982, 'Stress factors in coaching', Coaching Science Update 23, 47-49.

Lazarus, R.S \& Folkman, S., 1984, Stress, appraisal, and coping, Springer, New York.

Malone, C.J. \& Rotella, R.J., 1981, 'Preventing coaching burnout', Journal of Physical Education, Recreation and Dance 52, 22-27.

Mark, J., 'Coaches must stand and deliver', Saturday Star, 2 November, 2002, p. 17.

McAuley, E. \& Duncan, T.E., 1989, 'Causal attributions and affective reactions to disconfirming outcomes in motor performance', Journal of sport and Exercise Psychology 11, 187-200.

McNamara, J., 2007, 'Bouncing back from stress: resilient coaching', Coaching Australia 10(2), 1.

Minter, S.G., 1991, 'Relieving workplace stress', Occupational Hazards, April, 39-42

Misener, K. \& Doherty, A., 2009 'A case study of organizational capacity in nonprofit community sport', Journal of Sport Management 23(4), 457-482.

Mostert, K., \& Joubert, A.F., 2005, 'Job stress, burnout and coping strategies in the South African Police Service', SAJEMS 8(1), 39-53.

Parker, J.D.A. \& Endler, N.S., 1992, 'Coping with coping assessment: a critical review', European Journal of Personality 6, 321-344.

Patton, M.Q., 1990, Qualitative Evaluation and Research Methods, 2nd ed., Sage Publications, Inc., Newbury Park, California.

Pearlin, L.I. \& Schooler, C., 1978, 'The structure of coping', Journal of Health and Social Behavior 19, 2-21.

Pienaar, J. \& Rothmann, S., 2003, 'Coping strategies in the South African Police Service', SA Journal of Industrial Psychology 29(4), 81-90.

Rotter, J.B., 1966, 'Generalized expectancies of internal versus external control of reinforcements', Psychological Monographs, vol. 80. PMid:5340840

Sadri, G. \& Marcoulides, G.A., 1997, 'An examination of academic and occupational stress in the USA', International Journal of Educational Management 11(1), 32-43.

Singh P.C., 2001, 'The Job Security of Coaches', S.A. Journal for Research in Sport, Physical Education and Recreation 23(1), 65-73.

Smith, R.E., 1986, 'Toward a cognitive-affective model of athletic burnout', Journal of Sport Psychology 8, 36-50.

Steelman, T., 1995, 'Enhancing the youth sports experience through coaching', Parks \& Recreation 30(11), 14-16.

Surujlal, J., 2004, 'Human resources management of professional sports coaches in South Africa', Unpublished PhD thesis, Rand Afrikaans University, Johannesburg. 
Surujlal, J. \& Singh, P.C., 2007, 'Concerns of sport coaches: a qualitative study', African Journal for Physical, Health Education, Recreation and Dance, Special Edition June 2007, 84-96.

Taylor, J., 1992, 'Coaches are people too: An applied model of stress management for sports coaches', Journal of Applied Sport Psychology 1(4), 27-45.

Taylor, S.E., \& Brown, J.D., 1994, 'Positive illusions and well-being revisited separating fact from fiction', Psychological Bulletin 116(1), 21-27.

Van der Bijl, H. \& Oosthuizen, P., 2007, 'Anxiety, depression, health attitudes and coping strategies in doctors and teachers in a Cape Town setting', South African Journal of Psychology 13(2), 46-51.
Vealey, R.S., Udry, E.M., Zimmerman, V. \& Soliday, J., 1992, 'Intrapersonal and situational predictors of coaching burnout', Journal of Sport \& Exercise Psychology 14, 40-58.

Wolfson, S. \& Neave, N., 2007, 'Coping under pressure: cognitive strategies for maintaining confidence among soccer referees', Journal of Sport Behavior 30 232-247.

Wynd, T., 2007, 'Coach's corner: coaches make better people', Coaching Australia $10(2)$, p. 2.

Yong, Z. \& Yue, Y., 2007, 'Causes for burnout among secondary and elementary school teachers and preventative strategies', Chinese Education and Society 40(5), 78-85. 